\title{
PROPERTIES AND STRUCTURE OF NANOCRYSTALLINE LAYERS OBTAINED BY MANUAL METAL ARC WELDING (MMA)
}

\begin{abstract}
The present paper is the result of the investigations of the properties and structure of nanocrystalline layers deposited from iron-based nanoalloy on steel S355N substrate by manual metal arc welding method (MMA). In the process of welding a $100 \mathrm{~A}$ current intensity was used with desiccation preheating at $80^{\circ} \mathrm{C}$ while maintaining the interpass temperature at range of $200^{\circ} \mathrm{C}$. The resultant deposit welds were subjected to macro and microscopic metallographic examination, X-ray phase analyses and crystallite size was analyzed by X-ray diffractometry (XRD), additionally EDX chemical composition analysis of precipitates during scanning electron microscopy was performed. Working properties of the obtained nanocrystalline deposit welds were evaluated based on hardness and metal-to-mineral abrasive wear. The results of the deposit welds working properties measurements were compared with the properties of wear resistant steel HARDOX 400 type used as the reference material.
\end{abstract}

Keywords: nanocrystalline layers; crystallite size; manual metal arc welding; deposit weld

\section{Introduction}

For several years the research and development of new layered materials has been developing rapidly especially materials which are characterized by unique properties and structures in which newly formed layers show differing properties from previously formed layers. This is particularly true for material characteristics such as hardness, resistance to impact loads and a low coefficient of friction. The dynamic development of nanostructured materials shows promise for greater application in their use in welding technology in the future. The varying properties of nano-structured materials when compared to steel makes that the use of nanomaterials in welding technology brings new opportunities for their use. Nanomaterials are single or multi-phase polycrystals characterized by microstructural grain ranging in size from 1 to $250 \times 10^{-9} \mathrm{~m}$ [1-7]. At the upper end of this range, the term "ultra-fine particle size" (grain size of 250-1000 nm) is frequently used. Nanocrystalline materials are structurally characterized by a high volume fraction of grain boundaries which significantly alters their physical, chemical and mechanical properties as compared to conventional coarsegrained materials, whose particle size is usually within the range of 10-300 $\mu \mathrm{m}$. So far, nanomaterials, which compose nanostructural coatings exhibit a higher wear resistance when compared to conventional steel materials. However, nanostructured materials do not have wide use in welding technology mainly due to the high costs and ongoing development of their production technology. Currently there are relatively small classes of nanostructured materials available for use in technologies of layering by means of welding methods. So far, nanostructural material in the form of powders and wires are used in thermal spraying technology and techniques of GMA arc deposition and PTA. Recent work on new nanomaterials for industrial use are currently being conducted by the companies such as NanoSteel based in the USA [8-18].

\section{Purpose and course of study}

The aim of this research was to determine the properties and structure of the nanocrystalline surface layer of $\mathrm{Fe}-\mathrm{Cr}-\mathrm{Nb}-\mathrm{B}$ (Table 1), made by manual arc deposition with $3.2 \mathrm{~mm}$ diameter coated electrodes on the substrate made of S355N grade steel. The results of operating properties of layers are referenced to the properties of the HARDOX 400 grade steel. The attempts were performed by arc deposition method MMA with DC positive electrode polarity and a welding current of 100 [A] in the downhand position (PA), maintaining an interpass temperature of $200^{\circ} \mathrm{C}$. The process of deposition was conducted on a manufacturing line equipped with modern inverter welding source Caddy Tig 1500i TA34 providing high stability of the process. The electrode during deposition was set at an angle of 90 degrees relative to the substrate surface. The surfaces of S355N

\footnotetext{
* SILESIAN UNIVERSITY OF TECHNOLOGY, DEPARTMENT OF WELDING, 18 A KONARSKIEGO STR., 44-100 GLIWICE, POLAND

** SILESIAN UNIVERSITY OF TECHNOLOGY, INSTITUTE OF ENGINEERING MATERIALS AND BIOMATERIALS, 18 A KONARSKIEGO STR., 44-100 GLIWICE, POLAND 
steel sheets with dimensions of $180 \times 160 \times 10[\mathrm{~mm}]$ before the deposition process were ground and preheated by gas burner to a temperature of about $80^{\circ} \mathrm{C}$.

TABLE 1

The chemical composition and hardness of the weld used in the research

\begin{tabular}{|c|c|c|c|c|c|c|c|}
\hline \multicolumn{7}{|c|}{ Chemical composition, weight concentration, \%, } & \multirow{2}{*}{$\begin{array}{l}\text { The hardness of } \\
\text { the weld metal }\end{array}$} \\
\hline C & $\mathbf{C r}$ & B & $\mathbf{N b}$ & Mn & Si & Fe & \\
\hline 1,4 & 15,2 & 4,0 & 3,4 & 0,4 & 0,4 & Rest & $68 \div 70 \mathrm{HRC}$ \\
\hline
\end{tabular}

\section{Analysis of tests results}

\subsection{Base material analysis}

Macroscopic metallographic examination show that the resulting layers are free of porosity and contain weld line characteristic of the deposition process by coated electrodes (Fig. 1)

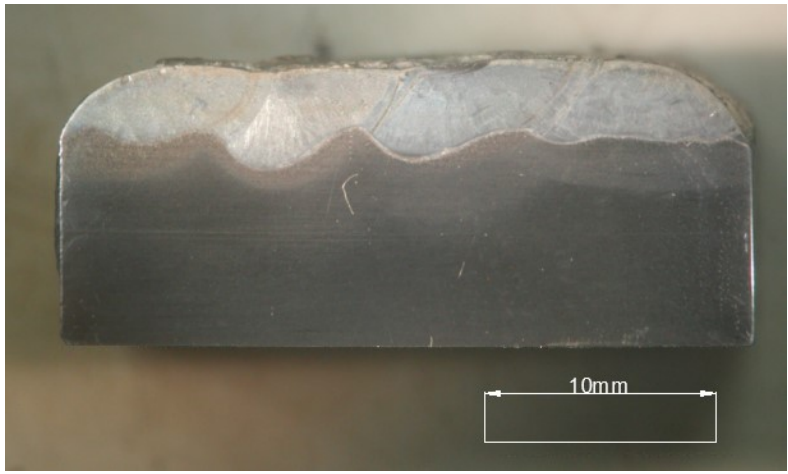

Fig. 1. Macrostructural view of nanocrystalline layers

In the welded layer cracks appear propagating from the surface to the substrate material.

The presence of these cracks does not reduce the operational properties and is even considered desirable in terms of metal- mineral type abrasion. Metallographic examinations revealed in the area of the deposit large amounts of primary carbides within high dispersion (Figs. 2,3).

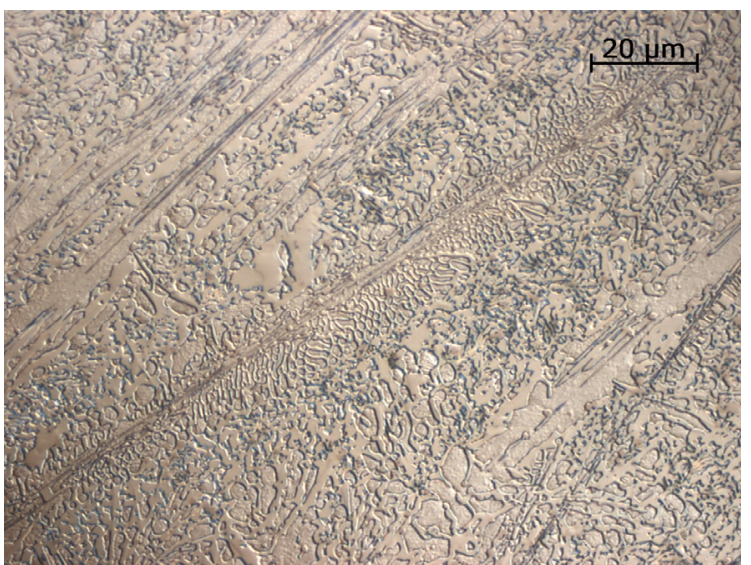

Fig. 2. Microstructure of nanocrystaline layer with eutectic like carbides

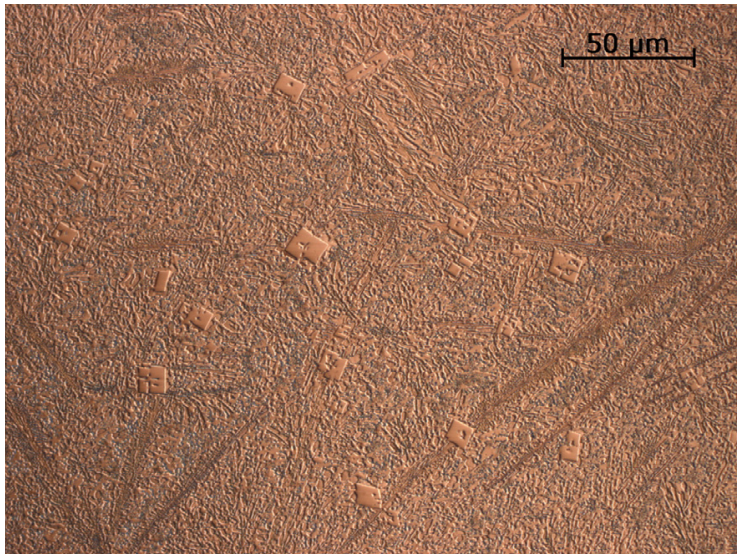

Fig. 3. Microstructure of nanocrystaline layer with carbide precipitates

Scanning electron microscope (SEM) analyses demonstrated that the observed smaller precipitation are niobium carbides and larger ones are complex chromium carbides (Figs. 4,5).

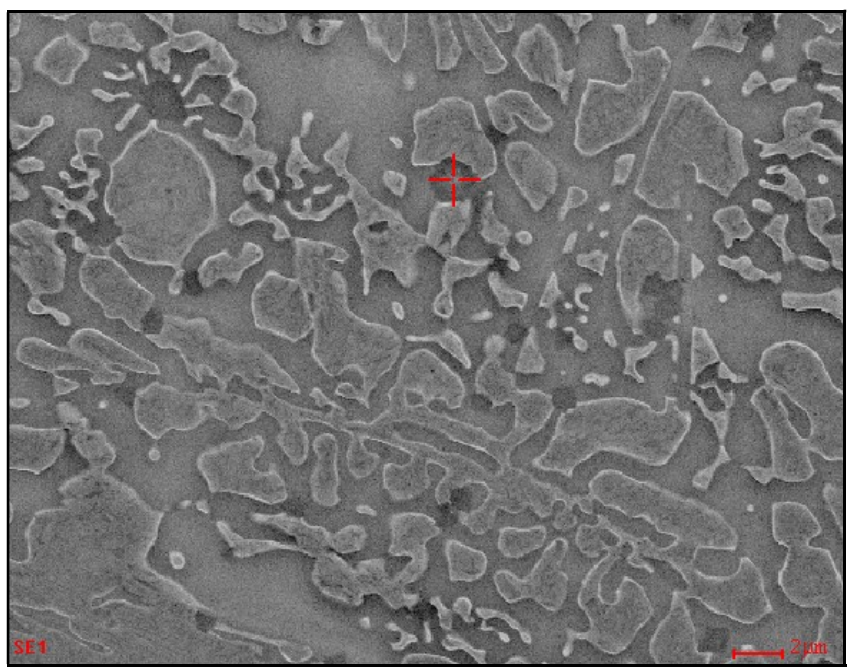

Fig. 4a. SEM image of nanstructural layer microstructure with EDS analyzing spot - precipitation of niobium carbide 


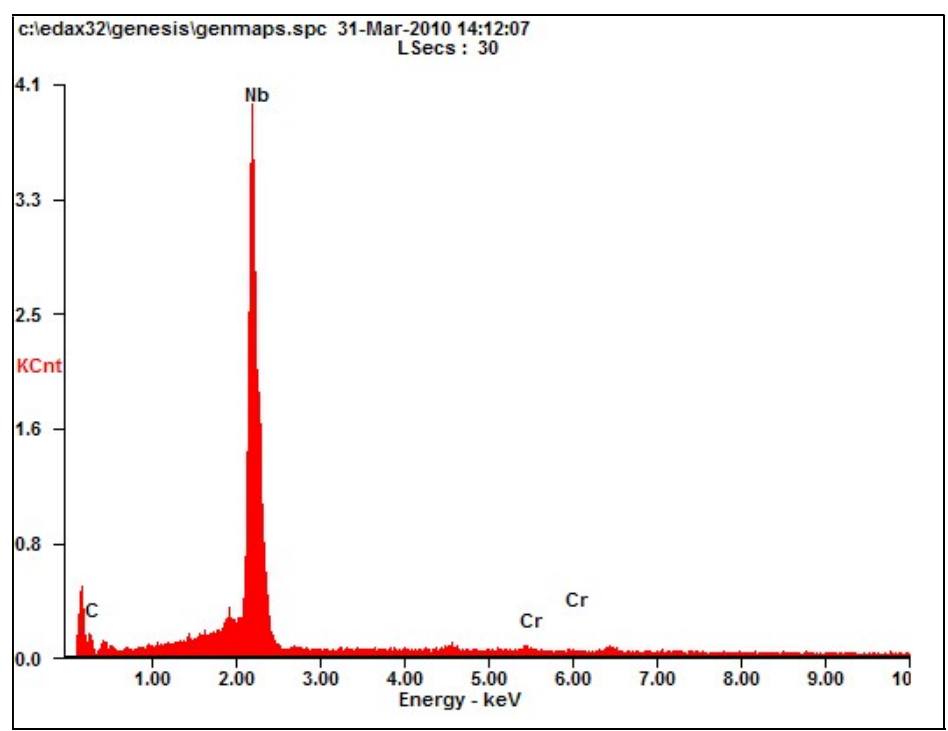

\begin{tabular}{c|l|l}
\hline Element & $\mathrm{Wt}, \%$ & $\mathrm{At}, \%$ \\
\hline $\mathrm{CK}$ & 32.90 & 75.36 \\
\hline $\mathrm{AlK}$ & 00.99 & 01.01 \\
\hline $\mathrm{NbL}$ & 48.94 & 14.49 \\
\hline $\mathrm{CrK}$ & 01.99 & 01.05 \\
\hline $\mathrm{FeK}$ & 07.60 & 03.74 \\
\hline Matrix & Correction & $\mathrm{ZAF}$ \\
\hline
\end{tabular}

Fig. 4b. The EDS spectrum of above indicated spot - separation of niobium carbide and results of quantitative analysis

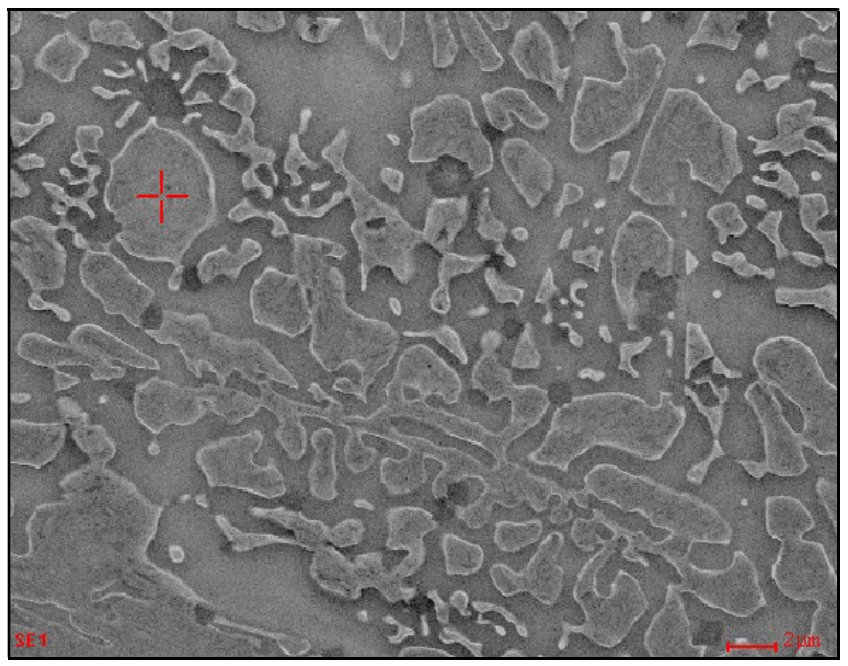

Fig. 5a. SEM image of nonstructural layer microstructure with EDS analyzing spot - precipitation of chromium carbide

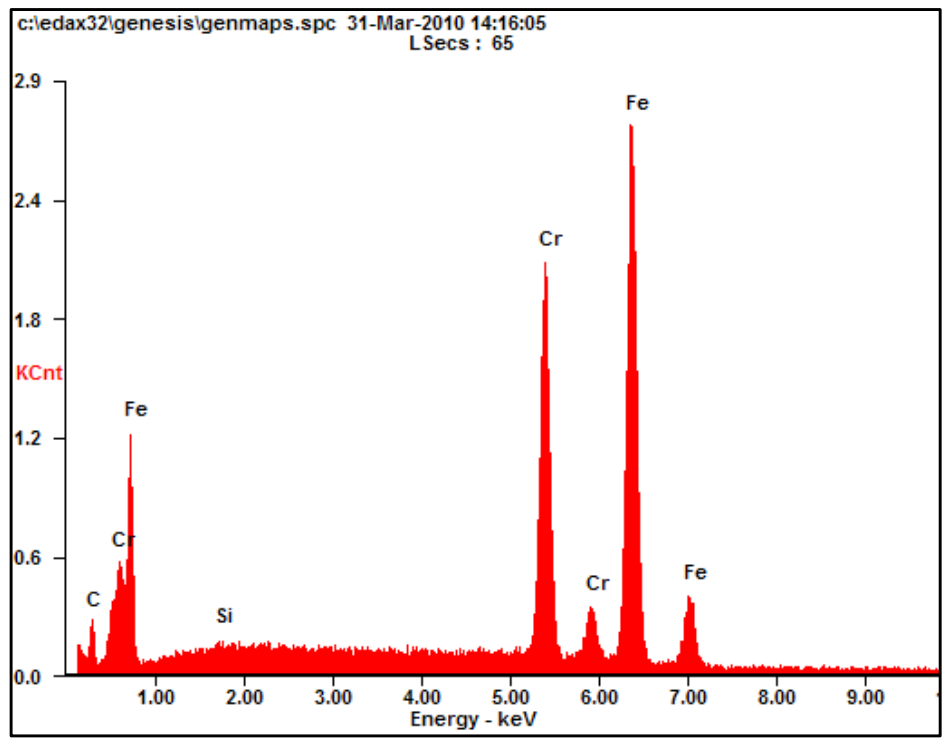

\begin{tabular}{l|l|l}
\hline Element & Wt, $\%$ & At, $\%$ \\
\hline $\mathrm{CK}$ & 19.22 & 52.00 \\
\hline $\mathrm{SiK}$ & 01.28 & 01.48 \\
\hline $\mathrm{CrK}$ & 25.98 & 23.74 \\
\hline $\mathrm{MnK}$ & 01.22 & 00.72 \\
\hline $\mathrm{FeK}$ & 52.30 & 32.06 \\
\hline Matrix & Correction & ZAF \\
\hline
\end{tabular}

Fig. 5b. The EDS spectrum of above indicated spot - separation of chromium carbide and results of quantitative analysis 
Measurement of the crystal grain size of the nanocrystalline microstructure of $\mathrm{Fe}-\mathrm{Cr}-\mathrm{Nb}-\mathrm{B}$ were performed on Xpert PRO PANalytical X-ray diffractometer equipped with a cobalt lamp at $40 \mathrm{kV}$ voltage and a filament current of $30 \mathrm{~mA}$ at an angular range of 30 to 120 degree. Calculations were carried out using the Scherrer equation (1) it was found that the average crystallite size of the microstructure of the deposited layer measured in a direction perpendicular to the welded layer onto substrate material was around $20 \mathrm{~nm}$.

$$
D=\frac{K \cdot \lambda}{B_{\text {struct }} \cdot \cos \theta}
$$

where: $D$ - the average size of the crystallite in the direction perpendicular to the planes of deflection, $K$ - Scherrer constant (close to unity) $\lambda$-wavelength $B_{\text {struct }}-$ width of reflexes, $\theta$ - the angle of reflection [5].
Analysis of the diffraction pattern of the nanocrystalline layers of $\mathrm{Fe}-\mathrm{Cr}-\mathrm{Nb}-\mathrm{B}$, showed the presence of reflections from the three types of carbides (Fig. 6):

- $\quad \mathrm{Cr}_{7} \mathrm{C}_{3}$ from the lattice plane (002), (151),(321), (202), (222), (260), (081);

- $\quad \mathrm{Cr}_{23} \mathrm{C}_{6}$ from the lattice plane (400), (420), (422), (333), (440), (531), (620), (911);

- $\quad$ NbC from the lattice plane (111), (200), (220).

Hardness measurements on the ground surface area of welds showed that the obtained nanocrystalline $\mathrm{Fe}-\mathrm{Cr}-\mathrm{Nb}$-B layer, show a measured hardness of $70 \mathrm{HRC}$ which is in accordance with the hardness specified by the manufacturer, Table 2.

Vickers hardness measurements on cross section of the weld showed that the hardness of the entire width is fixed at about $1000 \mathrm{HV} 1$, Fig. 7. The load of the diamond indenter was 1 [kg], the load operation time was 15 [s]. The measurement was made from the upper zone of the deposit in the direction of the base material at $0.25[\mathrm{~mm}]$.

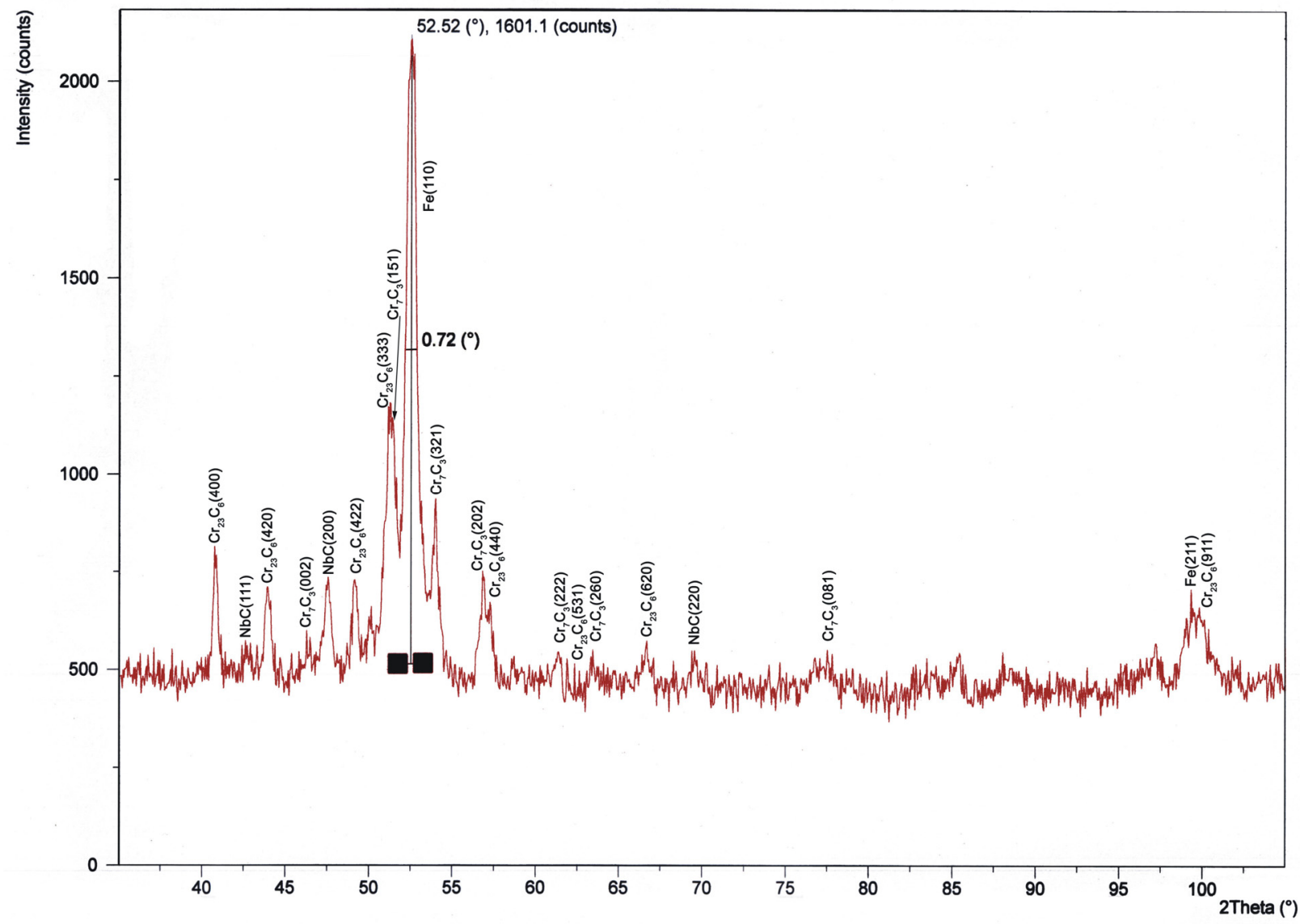

Fig. 6. The diffraction pattern of the nanocrystalline $\mathrm{Fe}-\mathrm{Cr}-\mathrm{Nb}-\mathrm{B}$ layer

The results of HRC hardness measurements on a surface area of welds

\begin{tabular}{|c|c|c|c|c|c|c|c|c|c|c|c|}
\hline \hline \multirow{2}{*}{$\begin{array}{c}\text { Specimen } \\
\text { designation }\end{array}$} & \multicolumn{10}{|c|}{ Hardness measurement points HRC } & $\begin{array}{c}\text { Average measurement } \\
\text { HRC }\end{array}$ \\
\hline Nano_01 & $\mathbf{1}$ & $\mathbf{2}$ & $\mathbf{3}$ & $\mathbf{4}$ & $\mathbf{5}$ & $\mathbf{6}$ & $\mathbf{7}$ & $\mathbf{8}$ & $\mathbf{9}$ & $\mathbf{1 0}$ & 7,3 \\
\hline HARDOX400 & 44,0 & 70,1 & 68,2 & 70,8 & 69,2 & 69,9 & 73,9 & 69,1 & 71,0 & 65,4 & 70,2 \\
\hline
\end{tabular}

Remarks: Distance between following points $-5,0[\mathrm{~mm}]$. The hardness of the base material S355N grade steel: $160-170 \mathrm{HV} 1$. 


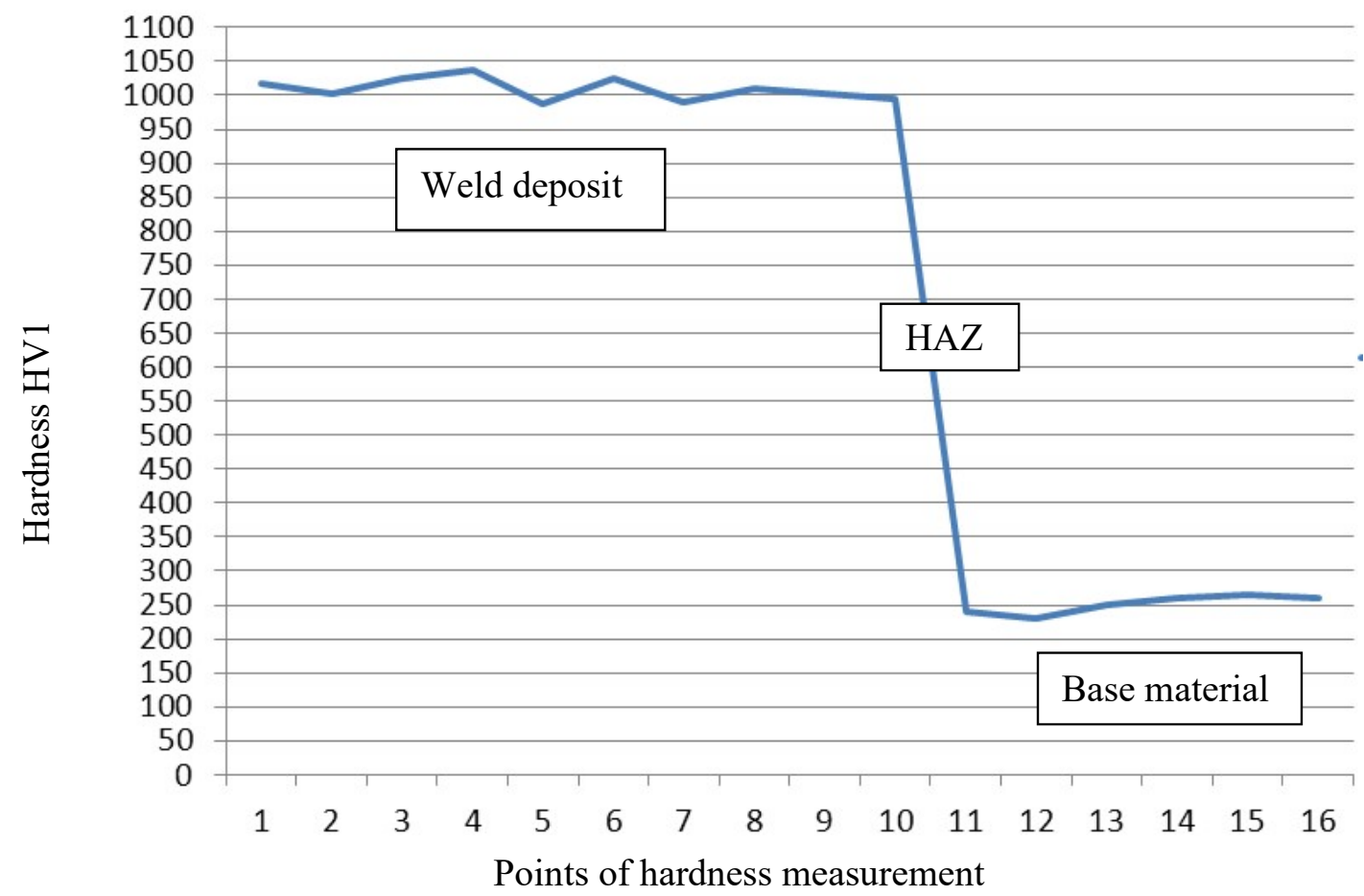

Fig. 7. Distribution of HV 1 hardness on the cross section of the weld

Research aimed at determining wear resistance of the deposited layers and HARDOX 400 type steel was performed according to ASTM G 65-00, Procedure A [6]. Tests were carried out on samples of dimensions $70 \times 25 \times 10[\mathrm{~mm}]$. The weight loss of the deposited samples were compared directly with the weight loss of samples from HARDOX 400 type steel. By using the measured density of the weld layer and weight loss of the sample the volumetric weight losses were calculated, Table 3. Conducted research indicates that the resulting layers are characterized by resistance to abrasion more than 14 times higher than steel HARDOX 400.

TABLE 3

Results of low-stress abrasion wear resistance test performed in accordance to ASTM G 65-00 Procedure A, on HARDOX 400 steel plate and $\mathrm{Fe}-\mathrm{Cr}-\mathrm{Nb}-\mathrm{B}$ deposit weld, metal-ceramic condition with dry quartz sand as the abrasion material

\begin{tabular}{|c|c|c|c|c|c|c|}
\hline $\begin{array}{c}\text { Specimen } \\
\text { designation }\end{array}$ & $\begin{array}{l}\text { Weight before test } \\
\text { [g] }\end{array}$ & $\begin{array}{c}\text { Weight after test } \\
\text { [g] }\end{array}$ & $\begin{array}{c}\text { Mass loss } \\
{[\mathrm{g}]}\end{array}$ & $\begin{array}{c}\text { Average mass loss } \\
{[\mathrm{g}]}\end{array}$ & $\begin{array}{c}\text { Average volume loss } \\
{\left[\mathrm{mm}^{3}\right]}\end{array}$ & $\begin{array}{l}\text { Relative* abrasion } \\
\text { resistance }\end{array}$ \\
\hline Nano_01 & 102,9477 & 102,8393 & 0,1084 & \multirow{2}{*}{0,1113} & \multirow{2}{*}{12,6765} & \multirow{2}{*}{14,65} \\
\hline Nano_02 & 101,7964 & 101,6821 & 0,1143 & & & \\
\hline Hardox_01 & 62,2260 & 60,7526 & 1,4734 & \multirow{2}{*}{1,4617} & \multirow{2}{*}{185,7306} & \multirow{2}{*}{1,00} \\
\hline Hardox_02 & 63,1222 & 61,6721 & 1,4501 & & & \\
\hline
\end{tabular}

Remarks: density of Fe-Cr-Nb-B deposit weld: $-8,78\left[\mathrm{~g} / \mathrm{cm}^{3}\right]$, the force applied against the test specimen $\mathrm{TL}=130[\mathrm{~N}]$. Volume loss, $\left[\mathrm{mm}^{3}\right]=\mathrm{mass}$ loss $[\mathrm{g}]$ : density $\left[\mathrm{g} / \mathrm{cm}^{3}\right] \times 1000$.

* - relative to HARDOX 400 steel plate.

\section{Conclusions}

Analysis of the attained results of the manual metal arc welded samples containing Fe-Cr-Nb-B have confirmed that the deposited layers are composed of crystallites on the order of $20 \mathrm{~nm}$ in width which allows them to be classified as nanocrystalline. Numerous carbide precipitates with empirical formula $\mathrm{Cr}_{7} \mathrm{C}_{3}, \mathrm{Cr}_{23} \mathrm{C}_{6}$ and $\mathrm{NbC}$ were observed and detected in the samples. Despite a high amount of boron in the chemical composition of the welds XRD analyses failed to identify any appreciable amount of boron containing compounds. Computer aided thermodynamic analyses of the chemical reactions and phase changes during the welding process demonstrate that the welds contain durable chromium borides with an empirical formula of $\mathrm{Cr}_{3} \mathrm{~B}_{4}$ and $\mathrm{Cr}_{5} \mathrm{~B}_{3}$. The attained nanocrystalline layers are characterized by a very high hardness on the order of up to 70 HRC. Cross sections showed a uniform hardness of 1000 HV1 throughout. The attained layers also possess excellent metal-mineral abrasion resistance which is calculated to be 14 times better than HARDOX 400 steel which is a typical high abrasion resistance steel used in metal-mineral wear applications. 


\section{REFERENCES}

[1] Ch.P. Jr Poole, F.J. Ownes, Introduction to Nanotechnology, Wiley-VCH, Weinheim (2003).

[2] S. Boncel, J. Górka, S. Milo, P. Shaffer, K. Koziol, Polym. Composite. 35 (3), 523-529 (2014)

[3] G. Heath, Nanotechnology and welding - actual and possible future applications, CASTOLIN-EUTECTIC SEMINAR, Brussels, Belgium, (2006).

[4] J. Górka, A. Czupryński, Applied Mechanics and Materials, 809810, 501-506 (2015).

[5] S. Boncel, J. Górka, S. Milo, P. Shaffer, K. Koziol, Mater. Lett. 116, 53-56 (2014)

[6] U. Reisgen, L. Stein, B. Balashov, C. Geffers, Materialwiss. Werkst. 39 (11), 791-794 (2008).

[7] A. Czupryński, J. Górka, M. Adamiak M, Metalurgija 55 (2), 173-176 (2016)
[8] A. Lisiecki, Metals 5 (1), 54-69 (2015).

[9] D. Janicki, M. Musztyfaga-Staszuk, Stroj. Vestn-J. Mech. E. 62 (6), 363-372 (2016).

[10] M. Żuk, J. Górka, A. Czupryński, M. Adamiak, Metalurgija 55 (4), 613-616 (2016).

[11] A. Grajcar, M. Różański, S. Stano, A. Kowalski, J. Mater. Eng. Perform. 23 (9), 3400-3406 (2014).

[12] T. Chmielewski, D. Golański, W. Włosiński, B. Pol. Acad. Sci-Tech. 63 (2), 449-456 (2015).

[13] A. Grajcar, K. Radwański, H. Krztoń, Solid State Phenomena, 203-204, 34-37 (2013).

[14] M. Opiela, J. Mater. Eng. Perform. 9, 3379-3388 (2014).

[15] D. Janicki, Opt. Laser Technol. 94, 6-14, (2017).

[16] T. Chmielewski, A. Golański, P. I. Mech. Eng. B-J. Eng. 225, 611-616 (2011)

[17] D. Golański, G. Dymny, M. Kujawińska, T. Chmielewski, Solid State Phenomena, 240, 174-182 (2015). 